\title{
VARIASI KADAR SUKROSA SEBAGAI BAHAN PEMANIS DALAM FORMULASI NUTRASEUTIKAL SEDIAAN GUMMY CANDIES SARI BUAH MARKISA KUNING (Passiflora edulis var. flavicarpa)
}

\author{
Feris Firdaus $^{1}$, Vicky Agung Kresnanto ${ }^{2}$, Fajriyanto ${ }^{3}$ \\ Direktorat Penelitian dan Pengabdian Masyarakat Universitas Islam Indonesia ${ }^{\text {, }}$ \\ Program Studi Farmasi Fakultas MIPA Universitas Islam Indonesia ${ }^{2}$ \\ Email:feris.firdaus@gmail.com
}

\begin{abstract}
Passion fruit (Passiflora edulis) is one kind of plant that is commonly grown by our society. In the yellow passion fruit (Passiflora edulis var. Flavicarpa) contained vitamin $C$ and vitamin $A$ which is very high. The usage of passion fruit juice as nutraceuticals products that are rich in vitamins $C$ and $A$ is still relatively rare. Demands of people who want to get an interesting kind of preparation and easy to use push of this study which aims to produce gummy candies. Gummy candies preparations were made using a base of corn syrup, a sweetener mannitol with sucrose content variation of $4.49 \%$, $8.98 \%, 13.47 \%, 17.96 \%$ and $22.45 \%$. Manufacture of yellow passion fruit juice using freeze drying method is performed on the resulting fruit juice. Organoleptic test was conducted after the yellow passion fruit juice formed. Testing the physical properties of the preparations which have become gummy candies include organoleptic testing, weights uniformity test and the level of preference test (hedonict test) by the respondents to the color, taste, smell and shape, then the results were compared with the requirements in the literature and the results of statistical analysis using one way anova. Formula 3 that was containing sucrose $13.47 \%$ is the best formula compared with other formula, a coefficient of variation for weight uniformity test was $2.91 \%$. While for organoleptic test and hedonict test for the color, flavor, smell and shape of the formula 4 by respondents indicated that the sucrose content of $17.96 \%$ has the best look and feel to become the most preferred formula by respondents.
\end{abstract}

Keywords: passion fruit, nutraceuticals, gummy candies

\section{PENDAHULUAN}

Tanaman markisa (Passiflora edulis) merupakan tanaman yang berasal dari Amerika Selatan yaitu negara Brasil, yang kemudian menyebar sampai ke Indonesia. Di negara asalnya markisa tumbuh liar di hutanhutan basah dan mempunyai ratusan spesies Passiflora. Di Indonesia, tanaman markisa dikembangkan di beberapa tempat antara lain di Sulawesi Selatan, Sumatera Utara, Sumatera Barat dan Lampung. Di Sulawesi Selatan dari 25.399 ha lahan yang berpotensi untuk pengembangan markisa, baru 4.411 ha yang ditanami dengan produksi 34.226 ton pada tahun 1997, sedangkan di Sumatera Barat pada tahun yang sama terdapat 2.710 ha tanaman markisa dengan produksi 12.710 ton (Anonim, 2009b).

Produksi markisa dari perkebunan rakyat bervariasi antara 5-10 ton ha per tahun, padahal produksi tersebut dapat ditingkatkan sampai 15 ton per ha per tahun. Selain itu harga jual buah markisa ditingkat petani sangat murah karena rasanya yang sangat masam. Dari aspek ketersediaan bahan baku tidak kesulitan, karena markisa tidak termasuk buah musiman, panen dapat dilakukan terus menerus, dengan interval 15 hari dan produksinya semakin meningkat dengan bertambahnya umur sampai tahun ke-6, dan akan menurun setelah tahun ke-7. Namun demikian tetap tergantung dengan perawatan tanaman, semakin terawat, umur berproduksi semakin lama.

Dalam $100 \mathrm{~g}$ daging buah markisa mengandung vitamin $\mathrm{C}$ sebanyak $30 \mathrm{mg}$ (50 \%) dan vitamin A sebanyak 1272 IU (25\%) dan berbagai jenis vitamin dan mineral lainnya. Kandungan fitokimia dalam markisa adalah harman, harmol, harmalin, passaflorine, harmine, karotenoid, viteksin, krisin dan isoviteksin. Sedangkan kandungan 
gizinya antara lainenergi, lemak, protein, serat, mineral kalsium, fosfor, zat besi, karoten, tiamin, riboflavin, niasin, dan asam sitrat (Anonim, 2009b).

Tanpa disadari, setiap hari tubuh manusia terpapar beragam racun, dari polusi, makanan tak sehat, obat - obatan, stres dan sebagainya. Untuk mempertahankan kesehatan, selain mengandalkan stamina, tubuh juga mengharapkan pasokan kekebalan dari luar, yakni melalui konsumsi makanan. Namun adakalanya konsumsi tersebut tidak berimbang. Nutrisi makro seperti karbohidrat, protein, lemak bisa terlihat saat makan, namun nutrisi mikro seperti vitamin, mineral yang terkandung dalam buah / sayur biasanya terlewatkan. Untuk itulah perlunya konsumsi suplemen.

Dunia kesehatan terus berkembang. Setelah era suplemen, kini muncul nutraceutical yang berasal dari kata nutra yang berarti nutrisi, dan ceutical yang berarti fungsi obat. Maksudnya adalah pemberian nutrisi tertentu untuk mengantisipasi masalah yang sekiranya muncul. Secara spesifik nutraceutical adalah pemberian nutrisi untuk mengatur fungsi biologis tubuh. Dengan baiknya fungsi biologi, diharapkan tubuh akan mengobati sendiri segala bentuk penyimpangan. Konsep ini lebih bersifat prospektif ke depan, tidak hanya sekadar mengobati atau mengatasi masalah.

Bentuk nutraceutical bisa bermacam macam, ada vitamin dan mineral dengan dosis relatif besar (dikenal dengan istilah orthomolecular), mikronutrien, bahan herbal, bentuk ekstraksi bahan alami (fitomedicin), enzim, asam amino, asam lemak esensial dan sebagainya. Nutraceutical yang beredar dimasyarakat sekarang ini cenderung mahal dan dan sediaan tidak terlalu bervariasi. Rata - rata sediaan yang beredar dimasyarakat sekarang ini hanya berbentuk tablet, tablet effervescent, minuman kesehatan. Respon masyarakat sekarang ini menuntut penggunaan nutraceutical yang murah dan penggunaannya praktis (Siregar, 2010). Di sisi lain, dengan berkembangnya ilmu pengetahuan dan teknologi di bidang farmasi mendorong para farmasis untuk membuat suatu formulasi yang tepat untuk mengolah bahan alam tadi menjadi suatu bentuk sediaan yang acceptable atau mudah diterima oleh masyarakat, selain parameter kualitas yang lain yang tetap harus terpenuhi. Dengan demikian, diharapkan dapat meningkatkan minat masyarakat dalam mengkonsumsi nutraceutical dari bahan alam.

Berdasarkan uraian di atas timbul suatu pemikiran yang melatarbelakangi dilakukannya penelitian tentang pembuatan bentuk sediaan tertentu menggunakan sari buah markisa. Dimana telah diketahui bahwa kandungan nutrisi buah markisa yang lengkap terlebih pada jumlah vitamin $\mathrm{C}$ yang mencapai $50 \%$ dan vitamin A yang mencapai $25 \%$. Sehingga diharapkan mampu memenuhi kebutuhan gizi vitamin $\mathrm{C}$ dan vitamin A terutama pada anak-anak karena bentuk sediaan yang dipilih dalam penelitian ini adalah permen kenyal (gummy candies), dimana sediaan ini masuk dalam kategori tablet kunyah (chewy).

Bentuk sediaan ini sangat diminati anak anak sehingga diharapkan dengan mengkonsumsi nutraceutical ekstrak buah markisa dalam bentuk gummy candies ini kebutuhan gizi terutama vitamin $\mathrm{C}$ dan vitamin A anak-anak dapat terpenuhi. Dalam hal tertentu bentuk sediaan ini relatif memiliki banyak keuntungan dibanding bentuk sediaan lain. Sehubungan hal tersebut, perlu dilakukan optimasi formula gummy candies ekstrak buah markisa berikut kontrol kualitasnya, sehingga akhirnya dapat diperoleh suatu sediaan gummy candies sari buah markisa yang memenuhi persyaratan kualitas. Gummy candies disukai karena mempunyai warna, bau dan rasa serta bentuk yang menarik. 


\section{METODE PENELITIAN}

\subsection{Bahan dan Alat}

Bahan yang digunakan adalah; buah markisa yang diperoleh dari sentra Markisa Organik Sleman, jalan Kaliurang, Hargobinangun, Kecamatan Pakem, Kabupaten Sleman, Yogyakarta. Bahan pembuatan gummy candies : Sari buah markisa, sirup jagung (Karo, ACH Food Companies USA), gelatin (Brataco Chemika, kualitas farmasetis), gom arab (Brataco Chemika, kualitas farmasetis), laktosa (Brataco Chemika, kualitas farmasetis), sukrosa (Gulaku, Sugar group Companies), essens makanan (Cap Koepoe-koepoe), minyak jagung (CHINA Corn Oil), manitol (Brataco Chemika, kualitas farmasetis). Alat pembuatan sari buah adalahb lender, penyaring, freeze dryer. Alat untuk membuat gummy candies : seperangkat alat gelas, neraca elektrik (Mettler Toledo type PL303), cetakan permen, waterbath (Memmert), spatula, pengaduk kaca, cawan porselin, pipet tetes, loyang.

\subsubsection{Skema Pembuatan Sediaan}

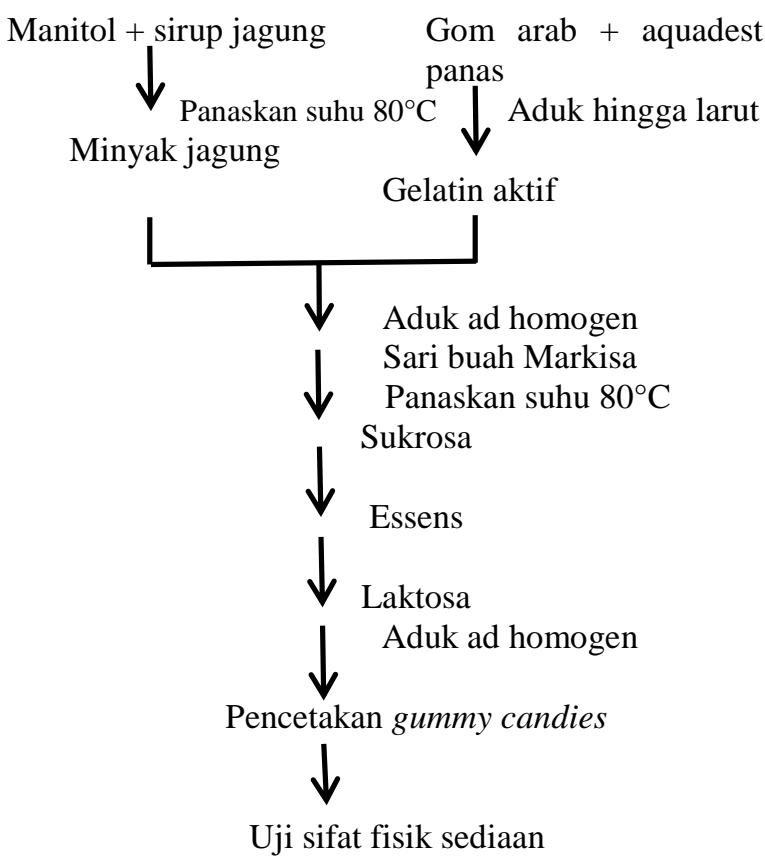

Gambar 1. Skema Pembuatan Sediaan.
Sampel buah markisa yang digunakan diperoleh dari Sentra Markisa Organik Sleman Jl. Kaliurang, Hargobinangun, Kecamatan Pakem, Kabupaten Sleman, Yogyakarta. Buah markisa diperoleh melalui proses sortasi, pencucian, pengambilan daging buah, dan penghalusan (pemblenderan). Sortasi dilakukan untuk memilih buah yang berkualitas dan memisahkan dari benda-benda asing yang tidak diinginkan. Buah markisa yang telah melalui proses sortasi kemudian dicuci dengan air mengalir untuk menghilangkan kotoran yang masih menempel pada buah sehingga bebas dari cemaran. Buah markisa disortasi, dicuci dan bersihkan, kemudian diambil daging buah dan dipisahkan dari biji buah. Daging buah tersebut di blender hingga menghasilkan sari buah markisa.

Tabel 1. Formula Gummy Candies Sari Buah Markisa (Passiflora Edulis).

\begin{tabular}{|c|c|c|c|c|c|}
\hline $\begin{array}{c}\text { Bahan } \\
(\mathrm{mg})\end{array}$ & F.1 & F.2 & F.3 & F.4 & F.5 \\
\hline $\begin{array}{c}\text { sari } \\
\text { buah }\end{array}$ & 300 & 300 & 300 & 300 & 300 \\
\hline manitol & 190 & 190 & 190 & 190 & 190 \\
\hline $\begin{array}{c}\text { corn } \\
\text { syrup }\end{array}$ & 538,65 & 538,65 & 538,65 & 538,65 & 538,65 \\
\hline gelatin & 760 & 760 & 760 & 760 & 760 \\
\hline $\begin{array}{c}\text { gom } \\
\text { arab }\end{array}$ & 28,5 & 28,5 & 28,5 & 28,5 & 28,5 \\
\hline laktosa & 190 & 190 & 190 & 190 & 190 \\
\hline essens & secukupnya & secukupnya & secukupnya & secukupnya & secukupnya \\
\hline $\begin{array}{c}\text { corn } \\
\text { oil }\end{array}$ & 99,75 & 99,75 & 99,75 & 99,75 & 99,75 \\
\hline sukrosa & 115 & 230 & 345 & 490 & 575 \\
\hline
\end{tabular}

Keterangan :

F.1 = Formula dengan konsentrasi Sukrosa 4,49\%

F. $2=$ Formula dengan konsentrasi Sukrosa 8,98 \%

F. $3=$ Formula dengan konsentrasi Sukrosa 13,47 \%

F. $2=$ Formula dengan konsentrasi Sukrosa 17,96 \%

F.3 = Formula dengan konsentrasi Sukrosa 22,45 \%

\subsection{Pembuatan Gummy Candies}

Proses pembuatan gummy candies ini diawali dengan mencampurkan basis gummy, yaitu manitol dan sirup jagung, kemudian dipanaskan dalam bejana seperti waterbath yang telah diisi aquadest dengan suhu $80^{\circ} \mathrm{C}$.

Kemudian ditambahkan minyak jagung. Penambahan minyak ini harus dalam keadaan panas, yaitu dengan suhu $80^{\circ} \mathrm{C}$ atau 
lebih untuk mendapatkan hasil akhir tablet yang kenyal dan mudah dikunyah. Jika penambahan di bawah suhu tersebut maka akan didapatkan hasil akhir tablet dengan rasa yang tebal dari minyak seperti berlemak saat dikunyah dan tidak kenyal.

Larutkan Gom arab di dalam $10 \mathrm{ml}$ aquadest panas pada gelas beaker yang terpisah. Di tempat lain aktifkan gelatin dengan cara memanaskannya di $15 \mathrm{ml}$ aquadest panas. Masukkan gelatin yang sudah aktif (larut) ke dalam larutan gom arab aduk hingga homogen. Kemudian campuran ini dimasukan ke dalam basis gummy.

Tambahkan sari buah markisa dan diaduk hingga homogen. Selanjtnya ditambahkan sukrosa, aduk hingga homogen. Kemudian tambahkan laktosa ke dalam campuran tersebut, aduk homogen. Setelah itu tambahkan essens secukupnya, dan aduk homogen. Usahakan semua bahan tambahan yang dimasukan ke dalam campuran diaduk secara perlahan tanpa menimbulkan adanya buih. Campuran tersebut kemudian dituang kedalam cetakan dan didinginkan. Gummy candies yang telah jadi kemudian diuji sifat fisiknya dan di analisis. Determinasi tanaman yang berpedoman pada buku acuan flora of java (Backer dan Brink, 1965), di laboratorium terpadu biologi farmasi fakultas MIPA UII Jogjakarta.

\subsection{Uji Sifat Fisik Sediaan}

Gummy candies diamati secara visual mengenai warna, rasa, aroma / bau, bentuk dan tekstur, apakah terjadi ketidak homogenan zat warna atau tidak, bentuk tablet, permukaan cacat atau tidak dan harus bebas dari noda atau bintik - bintik. Sejumlah 20 tablet ditimbang, hitung bobot rata - rata tiap tablet, jika ditimbang satu per satu tidak boleh lebih dari dua tablet yang bobotnya menyimpang lebih besar dari bobot rata-rata yang ditetapkan kolom A dan tidak satu pun yang bobotnya menyimpang dari bobot rata-rata yang ditetapkan pada kolom B. Harga koefisiensi variasi (CV) dihitung dengan menggunakan rumus (Anonim, 2009b)
$\mathrm{CV}=\frac{\mathrm{SD}}{\mathrm{X}} \times 100 \%$

Tabel 2. Persyaratan Penyimpangan Bobot Tablet (Anonim, 1979).

\begin{tabular}{|c|c|c|}
\hline \multirow{2}{*}{ Bobot Rata-Rata } & \multicolumn{2}{|c|}{$\begin{array}{c}\text { Penyimpangan Bobot } \\
\text { Rata-Rata }\end{array}$} \\
\cline { 2 - 3 } & A & B \\
\hline $25 \mathrm{mg}$ atau kurang & $15 \%$ & $30 \%$ \\
$26 \mathrm{mg}-150 \mathrm{mg}$ & $10 \%$ & $20 \%$ \\
$151 \mathrm{mg}-300 \mathrm{mg}$ & $7,5 \%$ & $15 \%$ \\
Lebih dari 300 mg & $5 \%$ & $10 \%$ \\
\hline
\end{tabular}

\subsection{Uji Tingkat Kesukaan (Hedonic test)}

Uji kesukaan pada dasarnya merupakan pengujian yang panelisnya menggunakan respon berupa senang atau tidaknya terhadap bahan yang diuji. Pada penelitian ini dilakukan uji kesukaan terhadap 20 responden berbagai usia dengan parameter yang diuji meliputi rasa, aroma, warna dan bentuk serta tingkat kesukaan responden terhadap tiap-tiap formula. Skala nilai yang digunakan adalah skala nilai numerik dengan nilai 1 sampai 3 . Nilai 1 menyatakan tidak suka, nilai 2 menyatakan suka, dan nilai 3 menyatakan sangat suka.

\subsection{Analisis Hasil}

Data yang diperoleh dari pengujian dibandingkan terhadap persyaratanpersyaratan dalam literatur yang ada. Keseragaman bobot sediaan sesuai dengan persyaratan yang ada dalam Farmakope Indonesia III. Data yang diperoleh dari uji sifat fisik tablet yaitu keseragaman bobot akan dianalisis secara statistik menggunakan uji statistik One Way ANOVA dengan taraf kepercayaan $95 \%$.

\section{HASIL PENELITIAN DAN PEMBAHASAN}

\subsection{Determinasi Tanaman}

Langkah pertama yang dilakukan dalam penelitian ini adalah mendeterminasi tanaman markisa (Passiflora edulis) secara makroskopik di Laboratorium Biologi Farmasi UII dengan tujuan untuk mencari kebenaran identitas dari tanaman yang akan 
diteliti dan agar tidak terjadi kesalahan terhadap tanaman yang akan digunakan. Determinasi dilakukan dengan mencocokkan keadaan morfologi tanaman dengan kuncikunci determinasi sesuai petunjuk literatur Flora of Java (Lachman, et al. 1994). Hasil determinasi rumus tanamannya adalah :

12b- 13b- 14b- 17b- 18b- 19b- 20b- 21aFam. 73. Passifloraceae-1b- 2. Passiflora .L- 3a- 4a- 5b- 8b-10a- Sp. Passiflora edulis .L. Dari hasil determinasi dapat dipastikan bahwa tanaman tersebut adalah tanaman markisa. Seperti telah diketahui bahwa buah markisa mengandung vitamin $\mathrm{C}$ sebanyak 30 mg $(50 \%)$ dan vitamin A sebanyak 1272 IU (25\%) dan berbagai jenis vitamin serta mineral lainnya. Oleh karena itu formulasi ini bertujuan untuk memformulasikan sari buah markisa dalam bentuk Gummy candies.

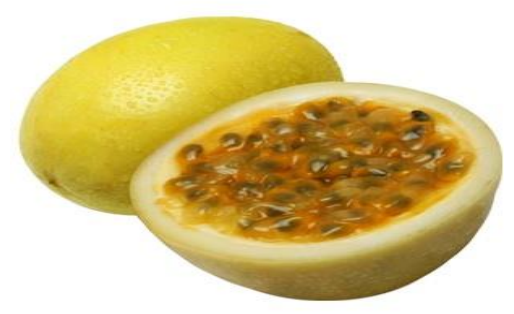

Gambar 2. Buah Markisa Kuning. (Passiflora edulis var. flavicarpa)

\subsection{Pemeriksaan Organoleptis Sari Buah Markisa}

Pembakuan atau karakteristik ekstrak (sari) perlu dilakukan karena ekstrak merupakan bahan baku obat tradisional yang mempunyai sifat dan karakteristik yang berbeda dengan bahan obat pada umumnya. Hal ini akan berpengaruh terhadap kualitas dan bentuk sediaan yang dibuat. Terpenuhinya standar mutu produk/bahan ekstrak tidak terlepas dari pengendalian proses, pengujian atau pemeriksaan persyaratan parameter standar umum ekstrak mutlak dilakukan dengan berpegang pada manajemen pengendalian mutu eksternal oleh badan formal (Anonim, 2000).
Uji sifat fisik sari dilakukan untuk mendapatkan kriteria - kriteria fisik dari sari buah markisa. Sari buah markisa didapat dari hasil pemblenderan buah markisa yang kemudian dikeringkan dengan metode freeze drying. Kriteria - kriteria tersebut nantinya akan menjadi patokan sifat fisik sari buah markisa pada produksi Gummy candies dan diharapkan akan diperoleh sediaan yang seragam dengan produksi sebelumnya.

Sebagai pengenalan awal terhadap sari buah markisa maka dilakukan pemeriksaan organoleptis yang meliputi bentuk, warna, bau dan rasa. Hasil pemeriksaan organoleptis sari buah markisa dapat dilihat pada Tabel 3;

Tabel 3. Pemeriksaan Organoleptis Sari Buah Markisa.

\begin{tabular}{|c|c|c|}
\hline No & $\begin{array}{c}\text { Pemeriksaan } \\
\text { Organoleptis }\end{array}$ & Hasil \\
\hline 1 & Bentuk & Massa semipadat \\
2 & Warna & Kuning kecoklatan \\
3 & Bau & Khas buah markisa \\
4 & Rasa & Sangat asam \\
\hline
\end{tabular}

Freeze drying atau proses beku - kering merupakan salah satu metode pengeringan yang memiliki kelebihan dalam mempertahankan mutu bahan yang dikeringkan seperti memelihara stabilitas aroma, warna, struktur dan kemampuan rehidrasi. Metode ini berbeda dari yang lain bahwa itu terjadi berdasarkan proses sublimasi pada suhu dan tekanan di bawah titik beku air $\left(0^{\circ} \mathrm{C}\right.$ dan $\left.613 \mathrm{~Pa}\right)$. Namun, karena air dalam materi umumnya mengandung zat larut, titik beku akan jauh di bawah $0^{\circ} \mathrm{C}$. Hal ini menyebabkan pembekuan dan karakteristik pengeringan yang berbeda untuk setiap material. Optimasi proses pengeringan - beku harus dimulai dengan pemahaman yang mendalam tentang mekanisme membekukan dan karakteristik pengeringan material yang sedang dikeringkan (Armansyah, et al. 2000). 
Material yang digunakan dalam proses beku kering ini adalah jus buah markisa. Pada gambar 11 dapat dilihat bahwa sari buah markisa yang telah mengalami proses freeze drying menghasilkan massa semipadat berwarna kuning kecoklatan. Berdasarkan hasil yang didapat seharusnya produk akhir proses beku kering berbentuk serbuk. Hal ini dapat terjadi karena kandungan gula (sukrosa) yang tinggi dalam buah markisa mencapai 11 gram dalam 100 gram buah markisa (Anonim, 2009a), sehingga proses pemanasan pada saat pengeringan terjadi harus dikendalikan untuk tetap berada dibawah suhu kritis sukrosa yaitu $-32^{\circ} \mathrm{C}$. Karena bila suhu tidak dipertahankan dapat terjadi fenomena runtuhnya struktur matriks beku dari material yang mengandung sukrosa yang dapat menyebabkan hasil akhir tidak berbentuk serbuk kering (Anonim, 2008).

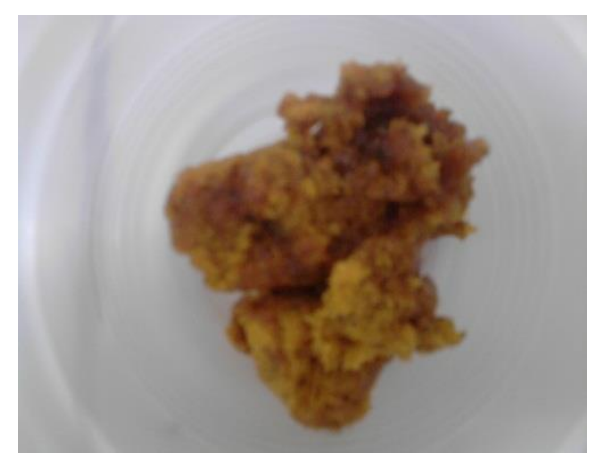

Gambar 3. Sari Buah Markisa.

\subsection{Hasil Uji Sifat Fisika Sediaan}

Proses pembuatan gummy candies ini diawali dengan mencampurkan basis gummy, yaitu manitol dan sirup jagung, kemudian dipanaskan dalam waterbath yang telah diisi aquadest dengan suhu $80^{\circ} \mathrm{C}$.

Kemudian ditambahkan minyak jagung. Penambahan minyak ini harus dalam keadaan panas, yaitu dengan suhu $80^{\circ} \mathrm{C}$ atau lebih untuk mendapatkan hasil akhir tablet yang kenyal dan mudah dikunyah. Jika penambahan di bawah suhu tersebut maka akan didapatkan hasil akhir tablet dengan rasa yang tebal dari minyak seperti berlemak saat dikunyah dan tidak kenyal.
Larutkan Gom arab di dalam $10 \mathrm{ml}$ aquadest panas pada gelas beaker yang terpisah. Di tempat lain aktifkan gelatin dengan cara memanaskannya di $15 \mathrm{ml}$ aquadest panas. Masukkan gelatin yang sudah aktif (larut) ke dalam larutan gom arab aduk hingga homogen. Kemudian campuran ini dimasukan ke dalam basis gummy. Tambahkan sari buah markisa dan diaduk hingga homogen. Selanjutnya ditambahkan sukrosa, aduk hingga homogen. Kemudian tambahkan laktosa ke dalam campuran tersebut, aduk homogen. Setelah itu tambahkan essens secukupnya, dan aduk homogen. Usahakan semua bahan tambahan yang dimasukan ke dalam campuran diaduk secara perlahan tanpa menimbulkan adanya buih.

Campuran tersebut kemudian dituang ke dalam cetakan dan didinginkan. Gummy candies yang telah jadi kemudian diuji sifat fisiknya dan di analisis. Sediaan yang diperoleh dari masing - masing formula diuji sifat fisika tablet yang meliputi uji organoleptis dan keseragaman bobot.

\subsection{Hasil Pemeriksaan Organoleptis}

Pemeriksaan organoleptis yang dilakukan meliputi bentuk, warna, bau, rasa dan tekstur. Berikut hasil uji organoleptis gummy candies tiap-tiap formula yang dapat dilihat pada tabel 4-8 dan bentuk sediaan gummy candies yang dihasilkan dapat dilhat pada gambar 4-8.

Tabel 4. Uji Organoleptis Gummy Candies Formula 1 (Sukrosa 4,49\%).

\begin{tabular}{|c|c|c|}
\hline No & $\begin{array}{c}\text { Pemeriksaan } \\
\text { Organoleptis }\end{array}$ & Hasil \\
\hline 1 & Bentuk & Bintang \\
2 & Warna & Kuning kecoklatan \\
3 & Bau & Khas buah markisa \\
4 & Rasa & Asam \\
5 & Tekstur & Kenyal sedikit keras \\
\hline
\end{tabular}




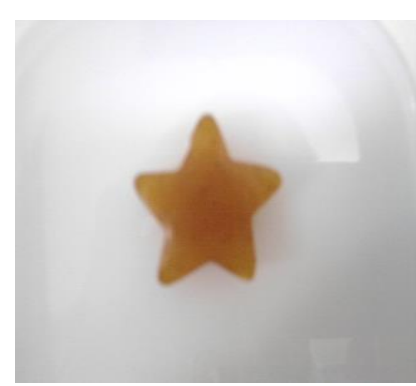

Gambar 4. Gummy Candies Formula 1.

Pada semua formula dihasilkan sediaan gummy candies dengan bentuk sesuai cetakan yang digunakan yaitu bintang. Dipilih bentuk bintang karena sediaan ini ditujukan kepada anak - anak, sehingga sediaan dibuat menarik dan disukai anakanak. Pada uji organoleptis terhadap warna dan aroma, sediaan yang dihasilkan pada formula 1 - 5 memiliki warna kuning kecoklatan dan beraroma khas markisa sesuai dengan warna dan aroma sari buah yang digunakan.

Sedangkan pada uji organoleptis terhadap rasa dan tekstur terdapat perbedaan pada tiap - tiap formula yang dihasilkan. Pada formula 1 rasa yang dihasilkan asam dan memiliki tekstur kenyal tetapi sedikit keras (gambar 4). Ini dikarenakan kadar sukrosa lebih rendah ada pada formula 1 dibandingkan formula 2, 3, 4 dan 5 yaitu 4,49\% sehingga tidak mampu menutupi rasa asam sari buah markisa dan berpengaruh pada tekstur yang kenyal dan sedikit keras.

Tabel 5. Uji Organoleptis Gummy Candies Formula 2 (Sukrosa 8,98\%).

\begin{tabular}{|c|c|c|}
\hline No & $\begin{array}{c}\text { Pemeriksaan } \\
\text { Organoleptis }\end{array}$ & Hasil \\
\hline 1 & Bentuk & Bintang \\
2 & Warna & Kuning kecoklatan \\
3 & Bau & Khas buah markisa \\
4 & Rasa & Asam \\
5 & Tekstur & Kenyal sempurna \\
\hline
\end{tabular}

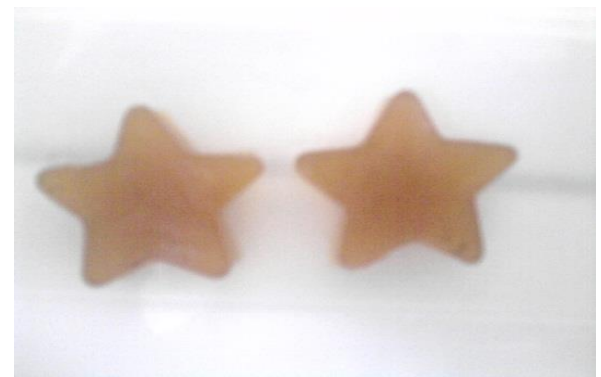

Gambar 5. Gummy Candies Formula 2.

Formula 2 (gambar 5) masih menghasilkan rasa yang asam dengan tekstur kenyal lebih baik dari formula 1. Pada formula ini kadar sukrosa 8,89\% yang digunakan belum mampu menutupi rasa asam sari buah yang digunakan. Pada formula 3 menghasilkan sediaan dengan rasa sedikit manis, ini menunjukan bahwa penambahan sukrosa sebesar $13,47 \%$ sebagai bahan pemanis pada sediaan ini sedikit dapat menutupi rasa asam dari sari buah markisa. Tekstur yang dihasilkan juga sesuai dengan harapan yaitu kenyal sempurna (gambar 6).

Tabel 6. Uji Organoleptis Gummy Candies Formula 3 (Sukrosa 13,47\%).

\begin{tabular}{|c|c|c|}
\hline No & $\begin{array}{c}\text { Pemeriksaan } \\
\text { Organoleptis }\end{array}$ & Hasil \\
\hline 1 & Bentuk & Bintang \\
2 & Warna & Kuning kecoklatan \\
3 & Bau & Khas buah markisa \\
4 & Rasa & Sedikit manis \\
5 & Tekstur & Kenyal sempurna \\
\hline
\end{tabular}

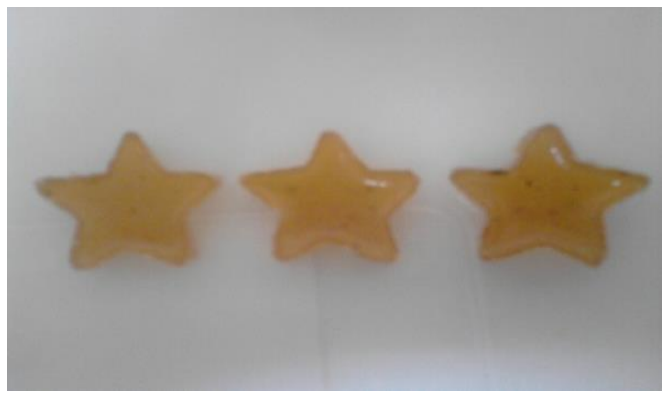

Gambar 6. Gummy Candies Formula 3. 
Pada formula 4 rasa yang dihasilkan yaitu manis, ini menunjukan bahwa kadar sukrosa $17,96 \%$ yang digunakan berhasil menutupi rasa asam sari buah markisa. Tekstur yang dihasilkan gummy candies formula 4 adalah kenyal sempurna (gambar 15). Pada formula 5, panambahan sukrosa sebagai bahan pemanis sebanyak $22,45 \%$ semakin menutupi rasa asam sari buah markisa yang digunakan. Tekstur yang dihasilkan pada formula 5 memiliki perbedaan yang cukup signifikan dibandingkan formula sebelumnya, sediaan yang dihasilkan memiliki rasa manis dengan tekstur kenyal tetapi cukup keras (gambar 8).

Tabel 7. Uji Organoleptis Gummy Candies Formula 4 (Sukrosa 17,96\%).

\begin{tabular}{|c|c|c|}
\hline No & $\begin{array}{c}\text { Pemeriksaan } \\
\text { Organoleptis }\end{array}$ & Hasil \\
\hline 1 & Bentuk & Bintang \\
2 & Warna & Kuning kecoklatan \\
3 & Bau & Khas buah markisa \\
4 & Rasa & Manis \\
5 & Tekstur & Kenyal sempurna \\
\hline
\end{tabular}

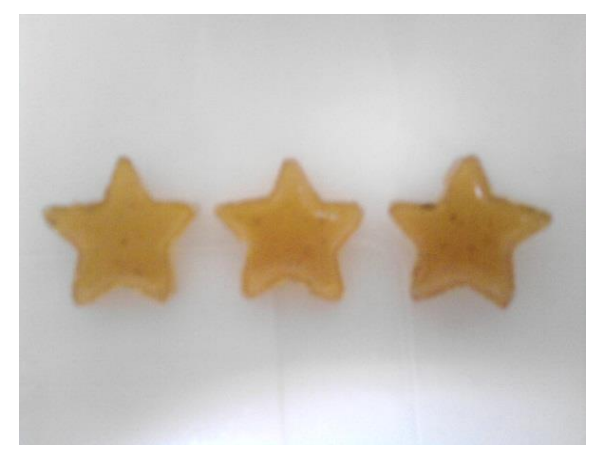

Gambar 7. Gummy Candies Formula 4.

Tabel 8. Uji Organoleptis Gummy Candies Formula 5 (Sukrosa 22,45\%).

\begin{tabular}{|c|c|c|}
\hline No & $\begin{array}{c}\text { Pemeriksaan } \\
\text { organoleptis }\end{array}$ & Hasil \\
\hline 1 & Bentuk & Bintang \\
2 & Warna & Kuning kecoklatan \\
3 & Bau & Khas buah markisa \\
4 & Rasa & Manis \\
5 & Tekstur & Kenyal cukup keras \\
\hline
\end{tabular}

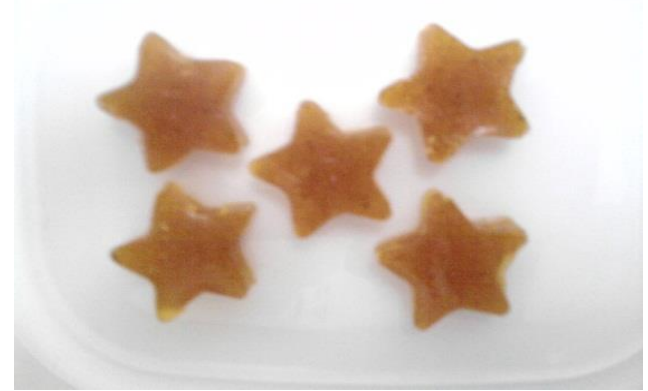

Gambar 8. Gummy Candies Formula 5.

Perbedaan tekstur yang dihasilkan pada masing - masing formula diakibatkan karena perbedaan jumlah kandungan air yang tersisa pada saat sediaan dituang ke dalam cetakan. Salah satunya yang mempengaruhi kandungan air pada tiap - tiap formula yaitu lamanya proses pembuatan yang dilakukan di atas waterbath. Lamanya waktu pemanasan yang tidak dikendalikan menyebabkan jumlah air yang menguap pada tiap - tiap formula tidak sama. Sehingga bila sediaan yang dihasilkan memiliki tekstur kenyal tetapi sedikit keras berarti sisa air yang ada lebih sedikit dibandingkan sediaan yang memiliki tekstur yang lebih kenyal seperti yang diharapkan pada sediaan gummy candies.

\subsection{Keseragaman Bobot}

Uji keseragaman bobot sediaan dilakukan untuk mengetahui bobot sediaan yang seragam dan uji ini dijadikan parameter produksi yang merupakan pengukuran secara rutin untuk mendapatkan bobot sediaan yang diinginkan. Keseragaman bobot secara tidak langsung menunjukkan keseragaman kandungan zat di dalam sediaan.

Faktor - faktor yang mempengaruhi keseragaman bobot tablet adalah bentuk cetakan dan suhu. Sering berubahnya pengaturan suhu dapat menyebabkan variasi bobot tablet, oleh karena itu diperlukan kontrol keseragaman bobot melalui pengaturan suhu dalam penyimpanan. Selain itu dengan pengukuran besarnya cetakan, sehingga dapat diperoleh bobot tablet sebesar 3 gram. Adapun hasil dari uji keseragaman bobot sediaan gummy candies 
pada tiap - tiap formula dapat dilihat pada grafik gambar 9 .

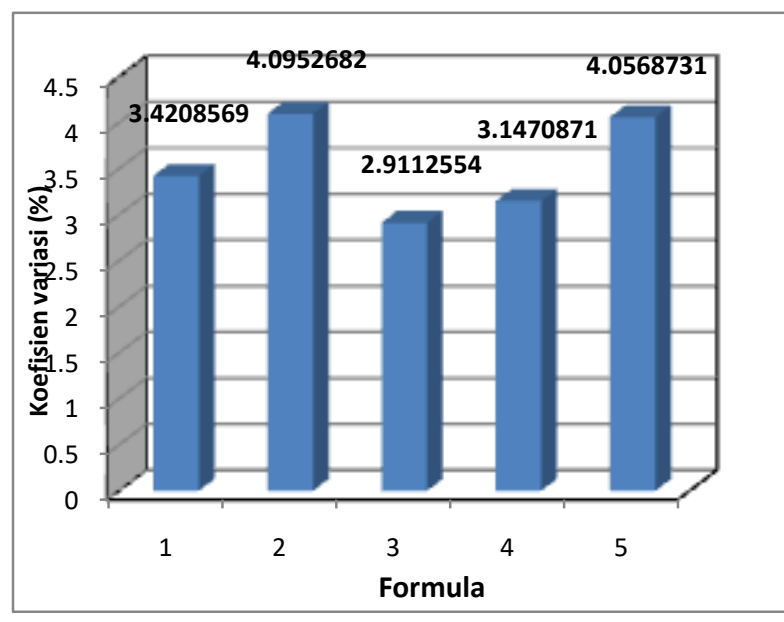

\section{Gambar 9. Pengaruh Kadar Sukrosa}

Terhadap Keseragaman Bobot.

Keterangan:

Formula 1 = Formula dengan variasi kadar sukrosa $4.49 \%$

Formula 2 = Formula dengan variasi kadar sukrosa $8.89 \%$

Formula 3 = Formula dengan variasi kadar sukrosa $13.47 \%$

Formula 2 = Formula dengan variasi kadar sukrosa $17.96 \%$

Formula 3 = Formula dengan variasi kadar sukrosa $22.45 \%$

Pada grafik keseragaman bobot tersebut dapat dilihat bahwa terdapat variasi profil grafik pada masing - masing formula. Adanya variasi ini dapat disebabkan oleh kondisi cetakan yang terbatas pada ukurannya yang tidak seragam. Selain itu, pada kondisi pemanasan yang tidak stabil dapat mempengaruhi proses penuangan ke dalam cetakan, sehingga sangat sulit untuk dituang dan mengakibatkan bobot tablet sangat bervariasi. Koefisien variasi yang dihasilkan dari masing - masing formula masih memenuhi syarat koefisien variasi yang diberikan yakni $<5 \%$.

Data yang diperoleh selanjutnya dianalisa statistik dengan SPSS menggunakan One Way ANOVA. Sebelum uji ANOVA, dilakukan uji statistik non parametrik yang bertujuan untuk mengetahui apakah data keseragaman bobot yang didapat terdistribusi normal atau tidak. Uji statistik non parametrik menggunakan One Sample
Kolmogorov - Smirnov, menunjukan data terdistribusi normal, sehingga data dapat langsung diolah uji statistik parametrik dengan One Way ANOVA. Hasil ANOVA keseragaman bobot menunjukkan nilai signifikan 0,000 (syarat $\mathrm{P}<0,05$ ), hal ini menunjukkan keseragaman bobot tablet memiliki nilai yang berbeda signifikan.

Kemudian untuk mengetahui perbedaan yang spesifik, dilanjutkan dengan menggunakan analisis statistik Tukey. Hasil statistik ternyata menunjukkan bahwa formula 5 memiliki perbedaan signifikan dengan keempat formula lainnya.

Berangkat dari hasil uji keseragaman bobot ini dapat disimpulkan bahwa berat tablet yang dicetak ditentukan oleh alat cetak yang sulit untuk dikalibrasi. Kestabilan pemanasan juga menentukan mudah atau tidaknya tablet dituang ke dalam cetakan karena pemanasan yang rendah akan membuat massa yang lebih padat, sehingga mempengaruhi keseragaman bobotnya. Sifat gula yang mempunyai melting point rendah menuntut kecepatan penuangan agar tablet tidak rusak karena pemanasan yang terlalu lama, sehingga suhu pelelehan harus selalu menjadi poin penting yang diperhatikan. Faktor - faktor tersebut sangat menentukan bobot tablet yang bervariasi. Untuk mengatasinya selama proses pencetakan perlu dilakukan pengujian bobot tablet secara berkala. Keseragaman bobot ditentukan berdasarkan atas banyaknya penyimpangan bobot tablet rata - rata yang masih diperbolehkan menurut persyaratan yang telah ditentukan.

\subsection{Hasil Uji Hedonik (tingkat kesukaan)}

Uji hedonik perlu dilakukan untuk melihat sejauh mana kesukaan responden terhadap gummy candies sari buah markisa yang telah dibuat. Pada uji ini dilakukan penilaian oleh 20 responden untuk semua formula, yang terdiri dari kerabat, sahabat, maupun mahasiswa dari berbagai jurusan dengan variasi usia. Pemilihan responden ini didasarkan pada faktor kesehatan dan usia. Parameter yang dapat digunakan untuk mengukur kesukaan responden terhadap 
tablet yaitu rasa, warna, aroma / bau dan bentuk. Aspek yang dinilai bertujuan untuk melihat tanggapan responden berdasarkan variasi kadar sukrosa sebagai bahan pemanis.

Tingkat kesukaan responden melalui uji tanggapan rasa, warna, aroma / bau dan bentuk serta kesukaan tiap formula dapat dilihat pada gambar 18 - 22, total skor yang didapat berasal dari jumlah nilai tiap - tiap formula yang diberikan responden dengan ketentuan bahwa nilai 1 berarti tidak suka, nilai 2 berarti suka dan nilai 3 berarti sangat suka.

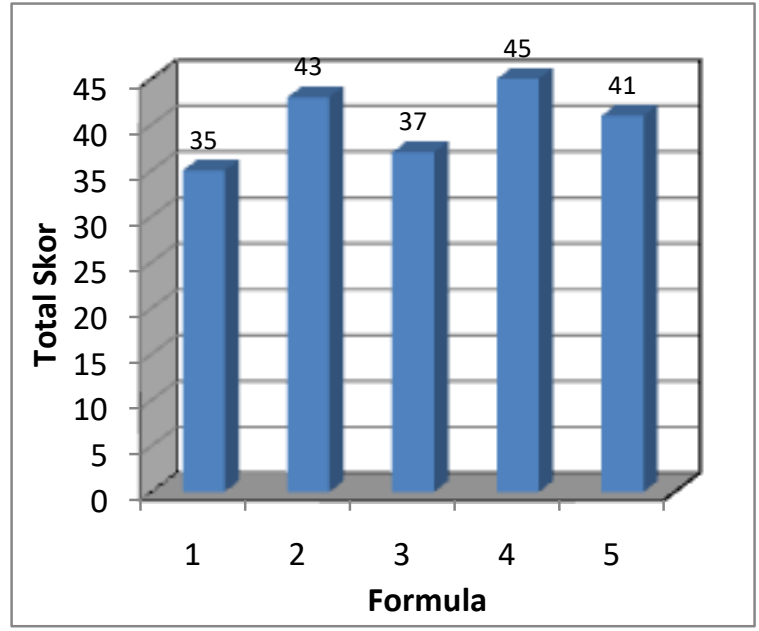

Gambar 10. Tingkat Kesukaan Responden

Keterangan: Melalui Uji Tanggapan Rasa.

Formula 1 = Formula dengan variasi kadar sukrosa $4.49 \%$

Formula $2=$ Formula dengan variasi kadar sukrosa $8.89 \%$

Formula 3 = Formula dengan variasi kadar sukrosa $13.47 \%$

Formula $2=$ Formula dengan variasi kadar sukrosa $17.96 \%$

Formula 3 = Formula dengan variasi kadar sukrosa $22.45 \%$

Hasil dari tingkat kesukaan responden melalui uji tanggapan rasa menunjukan bahwa formula 4 merupakan formula yang paling diterima oleh responden dengan total skor tertinggi yaitu 45 (gambar 10).

Kombinasi rasa manis dan asam yang pas, mampu dihasilkan formula 4 dengan kadar sukrosa $17,96 \%$. Skor terendah diperoleh formula 1 dengan kadar sukrosa 4,49\%. Formula ini memiliki skor terendah karena jumlah kadar pemanis tidak mampu menutupi rasa asam yang berasal dari sari buah markisa.

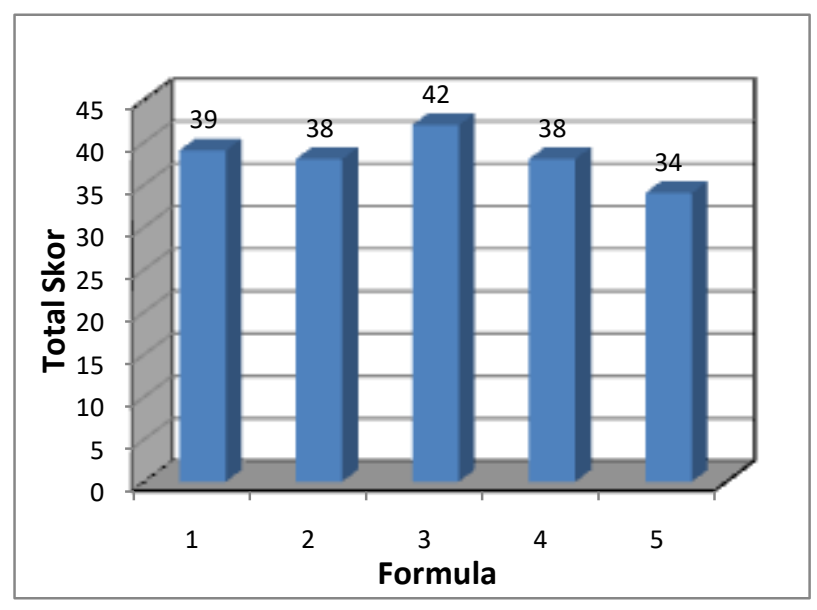

Gambar 11. Tingkat Kesukaan Responden Melalui Uji Tanggapan Warna.

Keterangan:

Formula 1 = Formula dengan variasi kadar sukrosa $4.49 \%$

Formula 2 = Formula dengan variasi kadar sukrosa $8.89 \%$

Formula 3 = Formula dengan variasi kadar sukrosa $13.47 \%$

Formula 2 = Formula dengan variasi kadar sukrosa $17.96 \%$

Formula 3 = Formula dengan variasi kadar sukrosa $22.45 \%$

Hasil tingkat kesukaan responden melalui uji tanggapan warna menunjukan bahwa formula 3 merupakan formula yang paling diterima oleh responden dengan total skor tertinggi yaitu 42 dan skor terendah diperoleh formula 5 yaitu 34 (gambar 11). Tampilan warna dari sediaan yang dihasilkan yaitu berasal dari sari buah markisa yang memiliki warna yang kuat untuk mempengaruhi sediaan yang dihasilkan serta penambahan sedikit pewarna makanan. Pada formula 3 mampu dihasilkan sediaan gummy candies dengan warna yang cerah dibandingkan formula lainnya karena zat pewarna yang digunakan mempu terdistribusi secara merata selama proses pembuatan. 


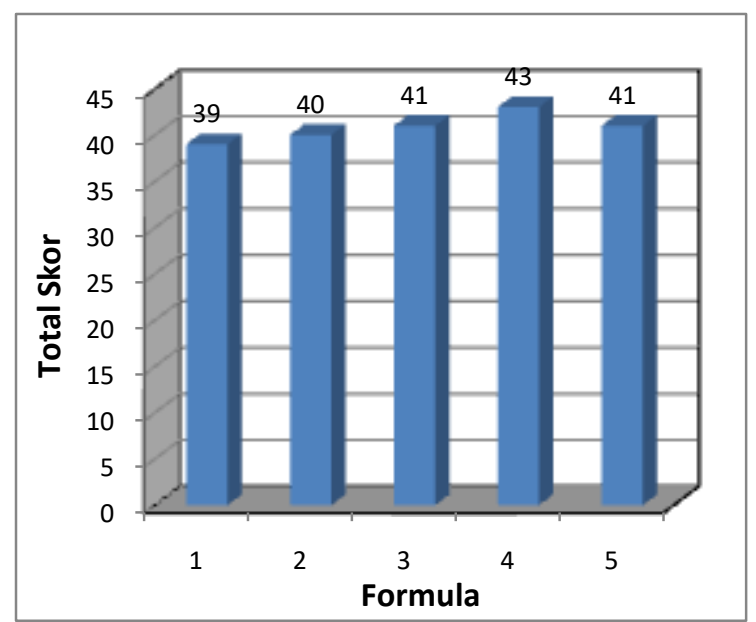

Gambar 12. Tingkat Kesukaan Responden

Keterangan:

Melalui Uji Tanggapan Aroma.

Formula 1 = Formula dengan variasi kadar sukrosa $4.49 \%$

Formula 2 = Formula dengan variasi kadar sukrosa $8.89 \%$

Formula 3 = Formula dengan variasi kadar sukrosa $13.47 \%$

Formula 2 = Formula dengan variasi kadar sukrosa $17.96 \%$

Formula 3 = Formula dengan variasi kadar sukrosa $22.45 \%$

Hasil tingkat kesukaan responden melalui uji tanggapan aroma / bau menunjukan bahwa tidak ada perbedaan skor yang signifikan pada tiap-tiap formula. Aroma / bau khas markisa yang dihasilkan berasal dari sari buah markisa yang digunakan dan essens markisa yang ditambahkan. Formula 4 menjadi formula yang paling disukai responden dengan total skor 43 (gambar 12).

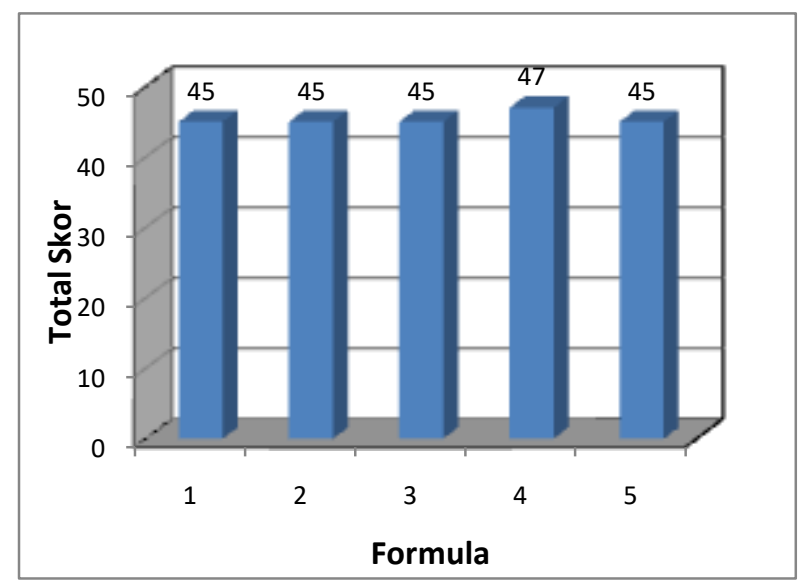

Gambar 13. Tingkat Kesukaan Responden Melalui Uji Tanggapan Bentuk.
Keterangan:

Formula 1 = Formula dengan variasi kadar sukrosa $4.49 \%$

Formula 2 = Formula dengan variasi kadar sukrosa $8.89 \%$

Formula 3 = Formula dengan variasi kadar sukrosa $13.47 \%$

Formula 2 = Formula dengan variasi kadar sukrosa $17.96 \%$

Formula 3 = Formula dengan variasi kadar sukrosa $22.45 \%$

Hasil tingkat kesukaan responden melalui uji tanggapan bentuk menunjukan hasil yang tidak jauh berbeda pada uji tanggapan aroma / bau, bahwa tidak ada perbedaan total skor yang signifikan pada tiap - tiap formula (gambar 13). Bentuk sediaan gummy candies yang dihasilkan mengikuti bentuk cetakan yaitu bintang. Seperti yang telah dikatakan sebelumnya bahwa bentuk bintang dipilih karena menghasilkan bentuk yang menarik dan disukai oleh anak - anak. Sehingga dengan kandungan vitamin $\mathrm{A}$ dan $\mathrm{C}$ yang ada pada buah markisa dapat dikonsumsi dan diterima oleh anak - anak dalam bentuk sediaan baru yang manarik yaitu sediaan gummy candies.

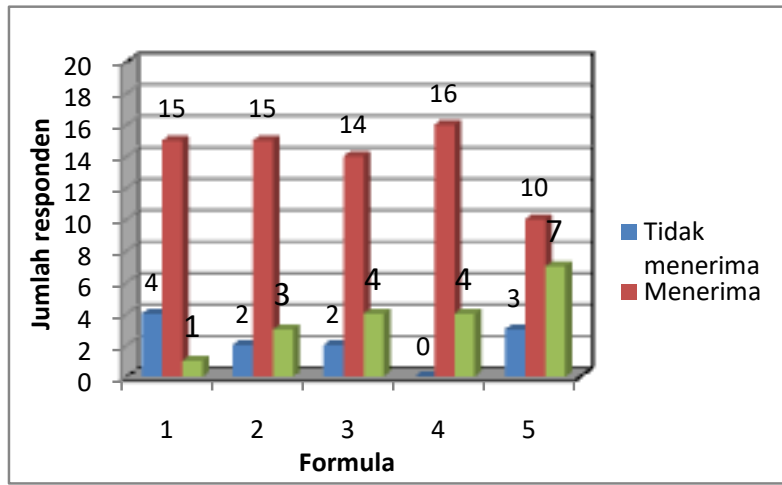

Gambar 14. Tanggapan Responden

Tentang Penerimaan Tiap Formula.

Keterangan:

Formula 1 = Formula dengan variasi kadar sukrosa $4.49 \%$

Formula 2 = Formula dengan variasi kadar sukrosa $8.89 \%$

Formula 3 = Formula dengan variasi kadar sukrosa $13.47 \%$

Formula 2 = Formula dengan variasi kadar sukrosa $17.96 \%$

Formula 3 = Formula dengan variasi kadar sukrosa $22.45 \%$ 
Dari segi kesukaan responden terhadap kelima formula, sebagian besar responden memilih formula 4 yaitu dari total 20 responden, 16 responden menyatakan menerima dan 4 responden menyatakan sangat menerima formula ini serta tidak satupun responden yang menolak formula 4 (gambar 22). Formula dengan variasi kadar sukrosa sebagai bahan pemanis sebesar $17,96 \%$ lebih disukai responden karena pada uji tanggapan rasa, aroma / bau serta bentuk memiliki total skor tertinggi dibandingkan formula lainnya yaitu $45,43,47$, hanya saja pada tanggapan warna hanya mendapatkan skor 38 .

\section{KESIMPULAN DAN SARAN}

Berdasarkan hasil penelitian yang telah dilakukan, pengumpulan, pengolahan, dan analisis data yang diperoleh, maka dapat ditarik kesimpulan bahwa sediaan gummy candies sari buah markisa yang dihasilkan telah memenuhi persyaratan sifat fisika tablet yang baik, diperoleh koefisien variasi pada uji keseragaman bobot untuk formula 1 , 2, 3, 4 dan 5 yaitu $3,42 \% \quad 4,10 \% \quad 2,91 \%$ $3,15 \%$ dan $4,01 \%$. Berdasarkan hasil uji sifat fisika, dapat disimpulkan bahwa dengan variasi kadar sukrosa sebagai bahan pemanis tidak mempengaruhi keseragaman bobotnya. Formula 4 dengan variasi kadar sukrosa sebagai bahan pemanis sebesar $17,96 \%$ merupakan formula yang paling disukai oleh responden.

Saran yang dapat diberikan adalah perlu dilakukan penelitian lebih lanjut untuk mengetahui hasil uji stabilitas sediaan gummy candies sari buah markisa tersebut dalam durasi waktu untuk mengetahui batas kadaluarsanya sebelum dilakukan produksi massal skala industri.

\section{UCAPAN TERIMAKASIH}

Ucapan terimakasih yang sebesarbesarnya disampaikan kepada Direktorat Penelitian dan Pengabdian Masyarakat Universitas Islam Indonesia Yogyakarta yang telah membiayai penelitian ini. Ucapan terima kasih juga disampaikan kepada semua pihak terkait yang turut serta membantu proses pelaksanaan penelitian ini hingga selesai.

\section{DAFTAR PUSTAKA}

Anonim, 2009a, Fitokimia Herba Konyal, available at http: // simonbwidjanarko.files.wordpress.c om/2008/07/ fitokimia-herbakonyal.pdf (diakses tanggal 25 Desember 2009).

Anonim, 2009b, Nutririondata, http://www.nutriondata.com/facts/fr uits-andfruit-juices/1987/2 ( diakses tanggal 25 Desember 2009).

Anonim, A Guide To Freeze Drying for the Laboratory, An Industry Service Publication, Labconco Corporation, Missouri, USA, 2008.

Anonim, Parameter Standar Umum Ekstrak Tumbuhan Obat dan makanan, Cetakan Pertama, Departemen Kesehatan Republik Indonesia, Direktorat Jenderal Pengawasan Obat dan Makanan, Direktorat Pengawasan Obat Tradisional, Jakarta, 5-6, 2000.

Anonim, Farmakope Indonesia, Edisi III, Departemen Kesehatan Republik Indonesia, Jakarta, 1000, 1979.

Armansyah H., Tambunan dan Manalu L. P., 2000, Mekanisme Pengeringan Beku Produk Pertanian, Jurnal Sains dan Teknologi Indonesia Vol.2, No.3, hal. 66-74 HumasBPPT/ANY,

http://www.iptek.net.id/ind/?mnu=8 $\&$ ch $=j$ sti $\& i d=174$ (diakses tanggal 28 Juli 2010). 
Becker, C. A., and Van De Brink, R. C. B., Flora Of Java, IV. V. P., Norordhoff-Groningen, The Netherlands, 1965.

Lachman, L, lieberman, H.A, Kanig, J.L, Teori dan Praktek Farmasi Industri II,edisi III, diterjemahkan oleh Siti Suyatmi dan Iis Aisyah, UI Press, Jakarta, 685,700,713, 1994.

Siregar, Dr. Amarullah H. DIHom., DNMed., MA, M.Sc., Ph.D., dan Toruan P., Dr., MM., Suplemen Sebagai Penyeimbang, Perkumpulan Awet Sehat Indonesia, http://www.tabloidnakita.com/artikel2.php3? edisi $=07$ $328 \&$ rubrik=klinikibu (diakses tanggal 1 Juni 2010). 